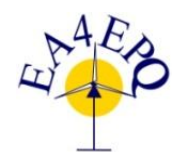

International Conference on Renewable Energies and Power Quality (ICREPQ'16)

Madrid (Spain), $4^{\text {th }}$ to $6^{\text {th }}$ May, 2016

$R$ enewableE nergy and $P$ ower $Q$ uality J ournal (RE\&PQJ)

ISSN 2172-038 X, No.14 May 2016

\title{
Estimated Environments Lighting Capacity Through Sunlight
}

\author{
Spacek, A. D. ${ }^{1-3}$, Santana, M. V. F de ${ }^{4-5}$, Mota, J. M. ${ }^{1-3}$, Biléssimo, L. D. ${ }^{1}$, Ando Junior, O. H. ${ }^{2}$, Freitas, \\ G. P. ${ }^{1}$, Pereira, T. C. ${ }^{1}$ \\ ${ }^{1}$ Departament of Mechanic and Automation \\ SATC, Beneficent Association of Santa Catarina Coal Industry \\ Street Pascoal Meller, 73. Criciúma-SC (Brazil) \\ Phone/Fax number: +55 48 3431-75.50, e-mail: anderson.spacek@ satc.edu.br, joao.neto@satc.edu.br, \\ luciano.bilessimo@satc.edu.br, gustavo.freitas@satc.edu.br, tiago.correa@satc.edu.br \\ ${ }^{2}$ Departament of Renewable Energies \\ UNILA, Federal University of Latin American Integration \\ Av. Sílvio Américo Sasdelli, 1842. Foz do Iguaçu-PR (Brazil) \\ Phone/Fax number: +55 45 3576-73.07, e-mail: oswaldo.junior@unila.edu.br \\ ${ }^{3}$ School of Engineering \\ UFRGS, Federal University of Rio Grande do Sul \\ Av. Osvaldo Aranha, 103. Porto Alegre-RS (Brazil) \\ Phone/Fax number: +55 51 3308-31.29 \\ ${ }^{4}$ Hidroelectric Power Plant \\ BAESA, Energética Barra Grande S/A \\ Street Madre Benvenuta, 1168. Florianópolis-SC (Brazil) \\ Phone/Fax number: +55 48 3331-0000, e-mail: marcus.santana@cscenergia.com.br \\ ${ }^{5}$ Hidroelectric Power Plant \\ ENERCAN, Campos Novos Energia S.A. \\ Street Madre Benvenuta, 1168. Florianópolis-SC (Brazil) \\ Phone/Fax number: +55 48 3331-0000, e-mail: marcus.santana@cscenergia.com.br
}

\begin{abstract}
This present paper is a study of the possibility of replacing conventional indoor light bulbs, by the daylighting trough domes and reflective tubes, which respectively capture and diffuse the sunlight to the interior environment. Base on collected data trough in a weather station, it is made a daily data collection and realized a projection of the sunlight which will focus on purpose study's system, according to the variations over the analyzed months. Wherefore, it is estimated the amount of replaced light bulbs and, therefore your economy. This kind of technology will allow the illumination will happen in a healthy and comfortable way.
\end{abstract}

\section{Keywords}

Sustainability, Sunlight, Renewable Energy.

\section{Introduction}

Economic growth in countries have in common the need of energetics resources as base to the increasing of productive sector. The sustainable development neither is a relevant factor in this expansion analysis, consequently reduces the environmental impact by the man on Earth [1, 2].
According to Empresa de Pesquisa Energética's (EPE) data, the consumption of electricity in Brazil will grow $3.7 \%$ per year until 2030. In this way, it needs the constant expansion of supply of energy and / or development systems more efficiently to follow the increased demand for electricity. Before this indicator is observed than the Brazil's territory is geographically located between Equator's line and the Tropic of Capricorn and has a high sunlight during all the year, values around $4.5 \mathrm{kWh} / \mathrm{m}^{2}$ to $5.5 \mathrm{kWh} / \mathrm{m}^{2}[3]$.

However, the increment in electricity demand over the long term has to be greater than the projection of availability. This growing demand drives the search for new alternatives generation and economic of power. In this regard the use of sunlight can help to attend the demand [4, 5].

Thus, there is a need for applied research to increase the means of direct sunlight use, as it is characterized by a natural raw material, abundant, inexhaustible and free, which can be used as energy source in lighting environments.

Studies indicate that $44 \%$ of the energy consumption of commercial and public sectors refers to the lighting and, befitting with national reality. Therefore, the development 
of strategies to reduce energy use target alternatives to the lighting system making it efficient and sustainable.

Before the Brazilian scene, the article presents a study of solar capture for the purpose of lighting indoors considering the variations of solar radiation over the months. At the second moment is compared your lighting capacity with artificial systems ordinarily used, in order to show an estimate reduction in electricity.

\section{Methodology}

In this paper was used data acquired by weather station Vantage Pro2, made by Davis Instruments, in the period from December / 2014 to Aug / 2015. This study used data acquired by weather station Vantage Pro2 (fig. 1) manufactured by Davis Instruments in the period from December / 2014 to Aug / 2015.

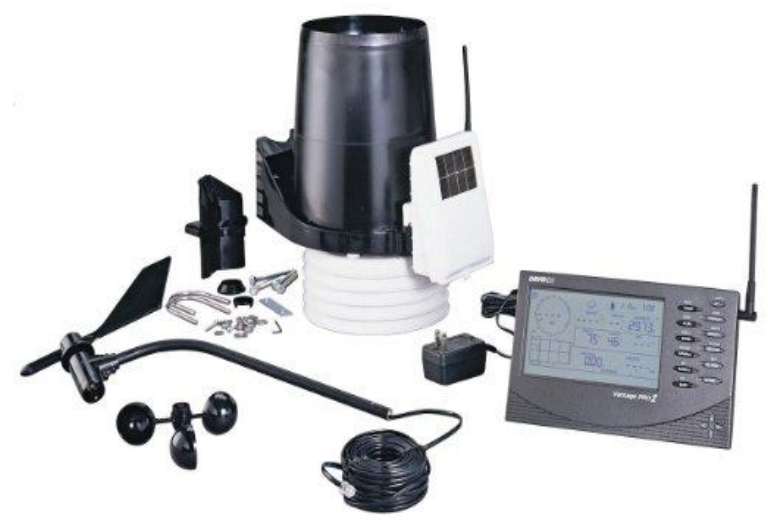

Fig. 1: Weather Station Vantage Pro2 - Davis Instruments (www.davisnet.com)

To ascertain the capacity of sunlight in the south of Santa Catarina, the weather station was installed in the facilities of the Faculdade SATC (fig. 2), the following coordinates $28.4^{\circ} \mathrm{S} 49.12^{\circ} \mathrm{W}$ and 32 meters above the sea level.

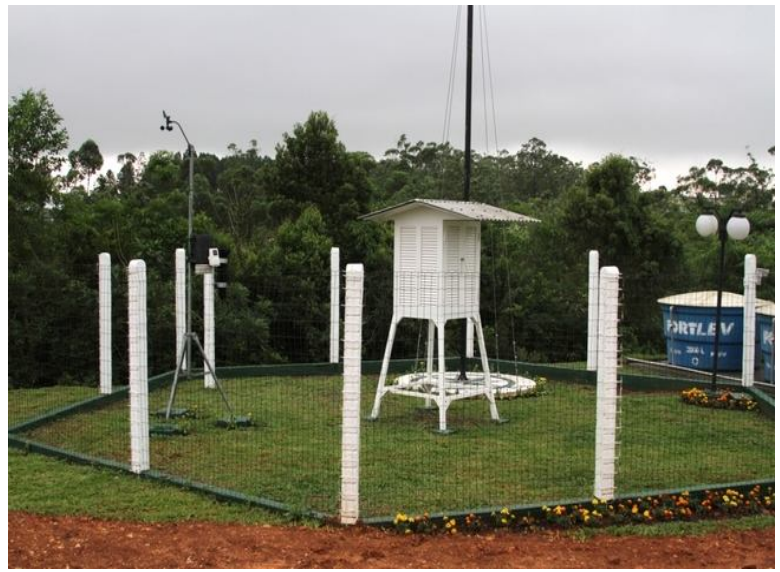

Fig. 2: Wheater Station location (Faculdade SATC)

For measuring the solar irradiation, the weather station was parameterized to perform data acquisition at 3-minute intervals. Through this acquisition is calculated the average value of each hour concerning the incidence in the area of one square meter.

The station performs the data recording over 24 hours. Hence it was decided that the daily period for analysis will include the range of 8:00 a.m. to 6:00 p.m. However, the data on sunlight outside this time range are irrelevant to the analysis proposed in this study.

Determined the daily range of analysis was performed in the average hourly of sunlight and consequently determined a characteristic average day of each month. In figure 3 , it can be observed the impact on the variation of the sunlight on the region during the months presented.

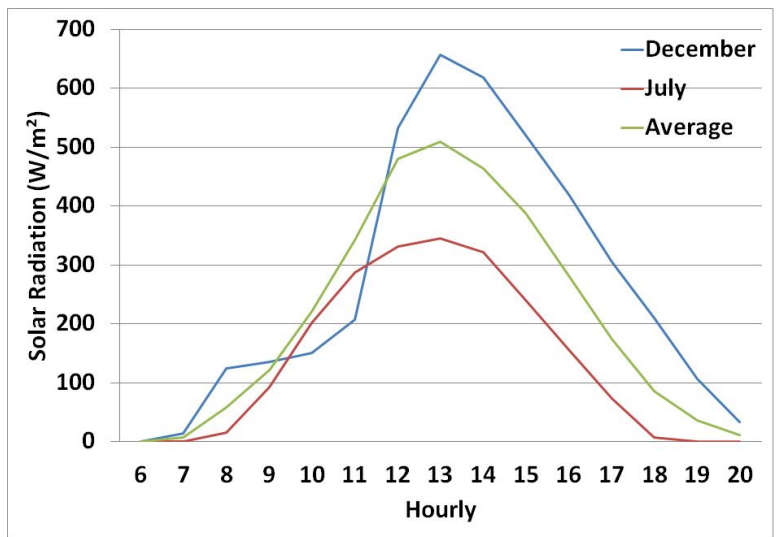

Fig. 3: Daily average sunlight $\left(\mathrm{W} / \mathrm{m}^{2}\right)$ in December 2014, July 2015 and average of nine months.

\subsection{Proposed system}

The proposed system defined for drive the natural light to the interior environment is made up of three main elements. At the top, a dome is responsible for redirecting the solar rays to the interior of a tube of $350 \mathrm{~mm}$ diameter. The tube is internally coated with a reflective material, in order to directing natural light into the environment. The light is captured, directed and distributed in the internal environment through an acrylic diffuser (fig. 4) homogeneously [6].

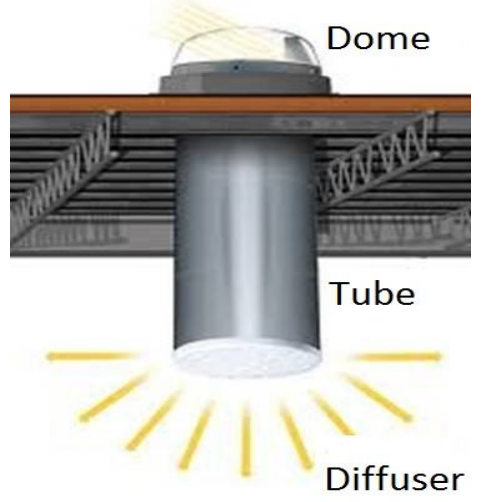

Fig. 4: Representation of a lighting system with reflective tube.

\subsection{Projection Lighting Capacity}

To make the comparison between the capacity of natural and artificial lighting, it is calculated the sunlight to 
the pipe $350 \mathrm{~mm}$ defined in the study. Therefore, the area of daylighting system exposed to the sun, is about $96,21 \times 10-3 \mathrm{~m}^{2}$. So the proportional projection of the incident rays in the reduced area is $9.62 \%(96,21 \times 10-3)$, being feasible to project the solar radiation in the natural lighting system showing in Figure 4. From the relation established, it is possible to obtaining a graph illustrating made with the projection, as according to Figure 5.

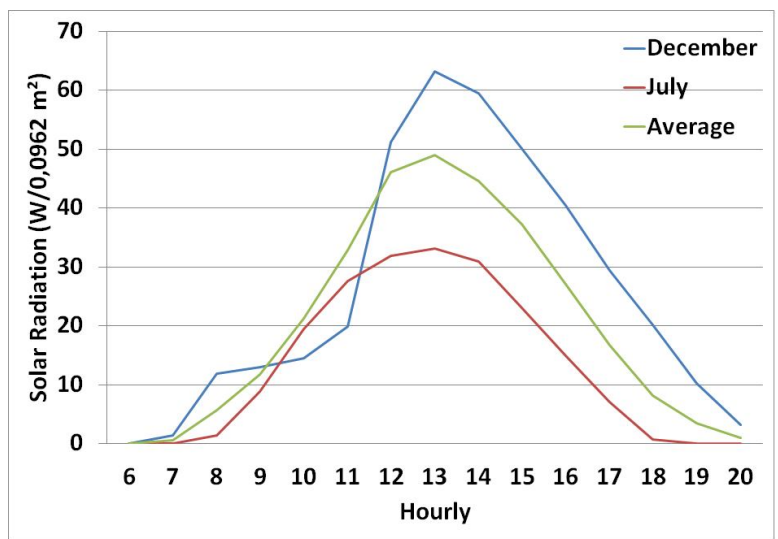

Fig. 5: Average daily solar radiation on a dome of $350 \mathrm{~mm}$, December 2014, July 2015 and average of nine months.

According to David Kaneda, a specialist in sustainable electrical systems and renewable energy, sunlight has high energy efficiency of approximately 105 lumens per watt of sunlight $[7,8,9]$. Based on this parameter was estimated generating capacity lumens of the proposed system in order to compare it with artificial lighting. However, according to the Espacio Solar Company, in a tube for commercial applications aimed indoor lighting, the internal reflectivity of the pipe is $98 \%$ [10]. So was used this reflectivity parameter as a correction factor for closer approach to the commercial products and to simplify calculations it was adopted the value of 100 lumens per watt for solar irradiation conversion, expressed by equation 1 :

$$
\text { Lumens }=100 \times \text { Watts Value }
$$

For comparison purposes it was defined that the tubular fluorescent lamp would be used, due to its comprehensive use for indoor lighting environment industrial, commercial, residential and sporting $[11,12]$. So it was used in the study, a Phillips tubular fluorescent lamp, model TL-D $36 \mathrm{~W} / 54-765$ 1SL that provides electrical power of $36 \mathrm{~W}$ and lighting capacity of 2500 lumens [13].

Spared lamps $=$ Lumens $\div 2500$

From the data collected in Figure 5, it is possible to estimate the incident sunlight in the dome during the set time and the average value. With the equations 1 and 2, the value was obtained in lumens which the system is able to emit and how many lamps could be substitute during the set time. The values obtained are shown in Table 1:
Table 1: Relation between solar radiation captured by a dome, and the amount of saved fluorescent lamps.

\begin{tabular}{|c|c|c|c|c|c|c|c|c|c|}
\hline $\begin{array}{c}\text { Hourly } \\
\text { (h) }\end{array}$ & $\begin{array}{c}\text { Dec } \\
\text { Watt } \\
\text { (W) }\end{array}$ & $\begin{array}{c}\text { Jan } \\
\text { Watt } \\
\text { (W) }\end{array}$ & $\begin{array}{c}\text { Feb } \\
\text { Watt } \\
\text { (W) }\end{array}$ & $\begin{array}{c}\text { Mar } \\
\text { Watt } \\
\text { (W) }\end{array}$ & $\begin{array}{c}\text { Apr } \\
\text { Watt } \\
\text { (W) }\end{array}$ & $\begin{array}{c}\text { May } \\
\text { Watt } \\
\text { (W) }\end{array}$ & $\begin{array}{c}\text { Jun } \\
\text { Watt } \\
(\text { W) }\end{array}$ & $\begin{array}{c}\text { Jul } \\
\text { Watt } \\
\text { (W) }\end{array}$ & $\begin{array}{c}\text { Aug } \\
\text { Watt } \\
(\text { W) }\end{array}$ \\
\hline $08: 00$ & 11,9 & 6,5 & 5,0 & 12,7 & 5,6 & 2,4 & 1,6 & 1,5 & 3,3 \\
\hline $09: 00$ & 13,0 & 11,3 & 12,2 & 19,7 & 7,7 & 11,1 & 12,9 & 8,9 & 8,9 \\
\hline $10: 00$ & 14,5 & 15,7 & 17,0 & 16,9 & 25,3 & 28,2 & 24,9 & 19,4 & 29,4 \\
\hline $11: 00$ & 19,9 & 24,5 & 33,3 & 39,4 & 41,2 & 35,9 & 33,9 & 27,6 & 40,6 \\
\hline $12: 00$ & 51,2 & 53,8 & 57,4 & 52,4 & 45,6 & 40,6 & 37,7 & 31,9 & 44,9 \\
\hline $01: 00$ & 63,2 & 61,7 & 59,7 & 54,8 & 43,8 & 38,9 & 37,2 & 33,1 & 48,8 \\
\hline $02: 00$ & 59,5 & 60,4 & 57,6 & 42,6 & 37,7 & 34,3 & 34,3 & 30,9 & 43,8 \\
\hline $03: 00$ & 50,1 & 50,4 & 48,9 & 39,2 & 31,4 & 27,6 & 28,3 & 23,1 & 36,3 \\
\hline $04: 00$ & 40,4 & 42,0 & 38,1 & 26,5 & 22,3 & 16,7 & 18,7 & 14,9 & 23,6 \\
\hline $05: 00$ & 29,4 & 34,0 & 24,1 & 18,0 & 12,2 & 7,0 & 7,0 & 7,1 & 11,5 \\
\hline $06: 00$ & 20,2 & 23,4 & 17,0 & 6,8 & 2,7 & 0,7 & 0,5 & 0,7 & 2,2 \\
\hline Min. & 11,9 & 6,5 & 5,0 & 6,8 & 2,7 & 0,7 & 0,5 & 0,7 & 2,2 \\
\hline Max. & 63,2 & 61,7 & 59,7 & 54,8 & 45,6 & 40,6 & 37,7 & 33,1 & 48,8 \\
\hline Average & 33,9 & 34,9 & 33,7 & 29,9 & 25,0 & 22,1 & 21,5 & 18,1 & 26,7 \\
\hline & & & & & & & & & \\
\hline $\begin{array}{c}\text { lumens } \\
\text { (lm) }\end{array}$ & $\mathbf{3 3 9 4}$ & $\mathbf{3 4 8 7}$ & $\mathbf{3 3 6 6}$ & $\mathbf{2 9 8 9}$ & $\mathbf{2 5 0 4}$ & $\mathbf{2 2 1 3}$ & $\mathbf{2 1 5 3}$ & $\mathbf{1 8 1 1}$ & $\mathbf{2 6 6 7}$ \\
\hline $\begin{array}{l}\text { Spared } \\
\text { lamps }\end{array}$ & $\mathbf{1 , 3 6}$ & $\mathbf{1 , 3 9}$ & $\mathbf{1 , 3 5}$ & $\mathbf{1 , 2 0}$ & $\mathbf{1 , 0 0}$ & $\mathbf{0 , 8 9}$ & $\mathbf{0 , 8 6}$ & $\mathbf{0 , 7 2}$ & $\mathbf{1 , 0 7}$ \\
\hline
\end{tabular}

\section{Analyses of results}

As presented in the study, the results emphasized in Table 1 are satisfactory, since, in six of the nine months analyzed will occur an average saving of one 2500 lamp lumens.

The moment with a higher incident sunlight in the dome displayed in Table 1 is at 1:00 p.m. hour in December 2014, with an average of 63.2 Watts. This value resulted to approximately 6320 lumens, which is equivalent to 2.52 lamps of 2500 lumens.

To complement the results is possible to analyze the financial economy based on the data presented in Table 1 . Considering which the lamps in question would be the same as the previous example (36W with 2500 lumens for tubular fluorescent) and with purpose to increase the scope of the study, it was included incandescent bulbs (typically $60 \mathrm{~W}$ with 644 lumens [14]), due to their low efficiency and although they are no longer produced, they still remain with great ordinarily use.

The lamps mentioned will be connected in the same proposed period from 08:00 a.m. to 06:00 p.m., and the residential rate for kilowatt hour, the place where the study was conducted, charged by the distribution company is from $\$ 0,44436$ [15]. Therefore from equation 3 it is possible to calculate the savings produced by this system, with the results shown in Table 2 . 


$$
\text { Saving }=H \times P \times N \times T
$$

Set up, where:

"H". Equals to amount of turned on lamp's hour over the month;

"P". Power in $\mathrm{kW}$ from the lamp in question;

"N". Amount of saved lamps;

"T". Price at current kW/hour.

Table 2: Estimate of how much money would be saved if the lamps mentioned were spared.

\begin{tabular}{|c|c|c|c|c|c|}
\hline MONTHS & Lumens & $\begin{array}{c}\text { Spared } \\
\text { fluorescent } \\
\text { lamps }\end{array}$ & $\begin{array}{c}\text { Saving } \\
(\mathrm{R} \$)^{1}\end{array}$ & $\begin{array}{c}\text { Spared } \\
\text { incandescent } \\
\text { lamps }\end{array}$ & $\begin{array}{c}\text { Saving } \\
(\mathrm{R} \$)^{2}\end{array}$ \\
\hline Dec & 3393,59 & 1,36 & $\mathrm{R} \$ 7,40$ & 5,27 & $\mathrm{R} \$ 47,91$ \\
\hline Jan & 3486,74 & 1,39 & $\mathrm{R} \$ 7,61$ & 5,41 & $\mathrm{R} \$ 49,22$ \\
\hline Feb & 3365,96 & 1,35 & $\mathrm{R} \$ 6,63$ & 5,23 & $\mathrm{R} \$ 42,92$ \\
\hline Mar & 2988,92 & 1,20 & $\mathrm{R} \$ 6,52$ & 4,64 & $\mathrm{R} \$ 42,20$ \\
\hline Apr & 2503,71 & 1,00 & $\mathrm{R} \$ 5,29$ & 3,89 & $\mathrm{R} \$ 34,21$ \\
\hline May & 2212,52 & 0,89 & $\mathrm{R} \$ 4,83$ & 3,44 & $\mathrm{R} \$ 31,24$ \\
\hline Jun & 2152,95 & 0,86 & $\mathrm{R} \$ 4,55$ & 3,34 & $\mathrm{R} \$ 29,41$ \\
\hline Jul & 1810,72 & 0,72 & $\mathrm{R} \$ 3,95$ & 2,81 & $\mathrm{R} \$ 25,56$ \\
\hline Aug & 2666,77 & 1,07 & $\mathrm{R} \$ 5,82$ & 4,14 & $\mathrm{R} \$ 37,65$ \\
\hline
\end{tabular}

With the reduction of consumption, the economy during the nine months studied would be $\mathrm{R} \$ 52.60$ for the case of fluorescent lamps of $36 \mathrm{~W}$, and $\mathrm{R} \$ 340.31$ for incandescent lamps of $60 \mathrm{~W}$.

\section{Conclusion}

It was confirmed with this study, despite the benefits when using natural lighting through reflective pipes, there is, by sunlight, a wide variation in the production capacity of the luminous flux. The sun, almost inexhaustible source of clean and renewable energy, does not maintain constant solar radiation incident on the earth's surface and, therefore, the inclusion of an automated system would be interesting for compensating the natural light by artificial light, which can It is made from the electrical energy storage in batteries through photovoltaic panels, either for night shifts or with overcast sky.

The use of alternative sources of illumination indirectly affects other aspects. Besides the economy, it is important to highlight the environmental gain because they make use of a clean source, decreased dependency on electricity, and reducing costs involved with correct disposal of burned out bulbs. Another motivation for performing the exchange, based on the heat generated to each $2 \mathrm{~kW}$ of artificial lighting should be offset with $1 \mathrm{~kW}$ of electric power for air conditioning [16].

The equipment available on the market and studied in this work have a high value and financial return occurs in the long term. Therefore, the search for environmentally friendly alternatives and methods for manufacturing of the studied system will contribute to its greater insertion in residential and industrial environments.

\section{Acknowledgement}

This project is being developed for under BAESA e ENERCAN for program of "Research and Development" regulated by ANEEL (3936-3314/2015). The authors would like thank to the BAESA and ENERCAN for supporting and facilities.

\section{References}

[1] MME, Ministério de Minas e Energia, e Empresa de Pesquisa Energética EPE. Balanço Energético Nacional - ano base 2009. Brasília, 2010.

[2] CHRISTANTE, L. A Eletricidade Subiu no Telhado. Unesp Ciência, São Paulo, v. 33, p. 18-25, aug. 2012

[3] COLLE, S.; PEREIRA, E. B. Atlas de Irradiação Solar do Brasil. Brasília: Inmet/Labsolar, 1998.

[4] SITHAN, Manimegalai; LAI, Loi Lei. Application of Green Technologies in Developing Countries - Reduced Carbon Emission and Conservation of Energy. Power and Energy Society General Meeting. San Diego, Ca, p. 1-7. jul. 2011.

[5] PALZ, Wolfgang. Energia Solar e Fontes Alternativas. Curitiba: Hemus, 2002. 358 p.

[6] SOLATUBE. Available at: 〈http://www.solatube.com/>. Access: 25 set. 2015.

[7] DEVLIN, Katy. Power of perception: Industry fights incorrect assumption that less glass is more effectual in energy-efficient building design. 2010. Available at: $<\mathrm{http} / /$ glassmagazine.com/article/commercial/powerperception-107268>. Access: 14 oct. 2015.

[8] KANEDA, David. Lighting/Daylighting/Electrical System Concepts for High Performance Schools. Available at: <https://www.cashnet.org/resourcecenter/resourcefiles/721.pdf $>$. Access: 15 oct: 2015.

[9] INTEGRAL GROUP (Org.). David Kaneda. Available at: <http://www.integralgroup.com/about-us/leadership/davidkaneda/>. Access: 15 oct. 2015.

[10] ESPACIO SOLAR (Org.). Catálogo Espacio Solar iluminação natural. Available at: <http://www.espaciosolar.com/fichas.htm>. Access: 15 oct. 2015.

[11] MONTEIRO, Raul Vitor Arantes et al. LED Tubular Lamps and Tubular Fluorescent: Power Quality. International Conference On Harmonics And Quality Of Power. Bucharest, p. 400-404. may 2014.

[12] OSRAM (Org.). Lâmpadas fluorescentes - uma abundância de luz com consumo de energia baixo. Available

at:

<http://www.osram.com.br/osram_br/noticias-e-

conhecimento/lampadas-fluorescentes/index.jsp>. Access: 15 oct. 2015

[13] PHILIPS (Org.). Catálogo Philips luz fluorescente básica. Available <http://download.p4c.philips.com/14bt/3/323102/tld_standard_colours_323102_ffs_brp.pdf $>$. Access: 15 oct. 2015.

[14] PHILIPS (Org.). Catálogo Philips luz incandescente softone. Available <http://download.p4c.philips.com/14b/9/920238642992_eu/ 920238642992_eu_pss_brpbr.pdf>. Access: 15 oct. 2015.

[15] ANEEL - Agência Nacional de Energia Elétrica (Org.). Tarifas Residenciais Vigentes. Available at: $\langle$ http://www.aneel.gov.br/area.cfm?idArea=493>. Access: 15 oct. 2015.

\footnotetext{
${ }^{1}$ Dollar exchange rate $\mathrm{R} \$ 3,86$
}

${ }^{2}$ Dollar exchange rate $\mathrm{R} \$ 3,86$ 
[16] SOUZA, Anádia Patrícia Almeida de. Uso da energia em edifícios: estudo de caso de escolas municipais e estaduais de Itabira, Minas Gerais. 2005. 142 f. Dissertação (Mestrado) - Curso de Tecnologia, Centro Federal de Educação Tecnológica de Minas Gerais, Belo Horizonte, 2005. 